Meta

Journal des traducteurs

Translators' Journal

\title{
Learner Needs Analysis for T\&I Program Reform
}

\section{Cheol-Ja Jeong}

Volume 50, numéro 4, décembre 2005

Pour une traductologie proactive - Actes

For a Proactive Translatology - Proceedings

Por una traductología proactiva - Actas

URI : https://id.erudit.org/iderudit/019866ar

DOI : https://doi.org/10.7202/019866ar

Aller au sommaire du numéro

\section{Éditeur(s)}

Les Presses de l'Université de Montréal

ISSN

0026-0452 (imprimé)

1492-1421 (numérique)

Découvrir la revue

Citer cet article

Jeong, C.-J. (2005). Learner Needs Analysis for T\&I Program Reform. Meta, 50(4). https://doi.org/10.7202/019866ar

\section{Résumé de l'article}

Cette communication vise à prendre en compte les perspectives des étudiants dans le cadre de la réforme de programmes de traduction et d'interprétation par le biais d'une analyse des besoins des étudiants, fait souvent négligé lors de la mise en pratique de la reconstitution d'un programme. Elle se sert d'un sondage au moyen d'un questionnaire auprès à la fois d'étudiants actuels et anciens, en vue d'examiner leurs marchés cibles et domaines de travail, pour vérifier si le contenu actuel des programmes d'enseignement est à même de préparer les apprenants à aborder de telles situations ciblées. Cette communication examine également les résultats de l'analyse des besoins afin de découvrir tout écart entre les besoins « perçus par les enseignants et ceux "ressentis par les apprenants ». En se basant sur les résultats d'une telle analyse, un renouvellement des programmes est proposé afin de mieux coordonner les intérêts et points de vue des parties prenantes, tant en matière d'enseignement que d'apprentissage.
Ce document est protégé par la loi sur le droit d'auteur. L'utilisation des services d’Érudit (y compris la reproduction) est assujettie à sa politique d'utilisation que vous pouvez consulter en ligne.

https://apropos.erudit.org/fr/usagers/politique-dutilisation/ 


\title{
Learner Needs Analysis for T\&I Program Reform
}

\author{
CHEOL-JA JEONG \\ Macquarie University, Sydney, Australia \\ cjeong@ling.mq.edu.au
}

\section{RÉSUMÉ}

Cette communication vise à prendre en compte les perspectives des étudiants dans le cadre de la réforme de programmes de traduction et d'interprétation par le biais d'une analyse des besoins des étudiants, fait souvent négligé lors de la mise en pratique de la reconstitution d'un programme. Elle se sert d'un sondage au moyen d'un questionnaire auprès à la fois d'étudiants actuels et anciens, en vue d'examiner leurs marchés cibles et domaines de travail, pour vérifier si le contenu actuel des programmes d'enseignement est à même de préparer les apprenants à aborder de telles situations ciblées. Cette communication examine également les résultats de l'analyse des besoins afin de découvrir tout écart entre les besoins « perçus par les enseignants » et ceux « ressentis par les apprenants ». En se basant sur les résultats d'une telle analyse, un renouvellement des programmes est proposé afin de mieux coordonner les intérêts et points de vue des parties prenantes, tant en matière d'enseignement que d'apprentissage.

\footnotetext{
ABSTRACT

This paper attempts to reflect learners' perspectives of the program in a program reform through learner needs analysis that is often neglected in the practice of program renewal. It uses a questionnaire survey conducted with both current and past students of the program to investigate the learners' target markets and areas of work, checking if the current content of teaching can prepare the learners for such target situations. It also looks into the results of the needs analysis for any discrepancy between the needs 'perceived by the teachers' and the ones 'felt by the learners'. Based on the results of such analysis, a program renewal is proposed to better coordinate the interests and views of the parties involved in the teaching and learning.
}

\section{MOTS-CLÉS/KEYWORDS}

needs analysis, questionnaire survey, target situation analysis, program reform/renewal, objectives oriented and process oriented curriculum 


\section{Introduction}

In planning any teaching, a needs and means analysis is considered a pre-requisite to setting of goals and objectives. While a number of researchers and experts in curriculum development and evaluation (Berwick 1989; Markee 1997; Seedhouse 1995; West 1994) emphasise its importance, they simultaneously acknowledge that it is not easy to conduct it in real situations, therefore, the difficulty in finding a program established on a clearly identified set of needs and means.

As educational plans, translation and interpreting programs are no exceptions to this. By employing active practitioners as lecturers, probably more numerous than in other fields of study, translation and interpreting programs assume that lecturers will represent well what their learners need to learn for their future careers. This assumption, however, needs to be checked.

Conducted as part of the regular review of a 10 year old translation and interpreting program, this research attempts to investigate the students' needs to find out whether the program meets them or whether improvements to any part of the teaching are required. It specifically surveys where the past students are working now; what they found useful or not useful in the program in preparation for their jobs; and what they would like to change or add to the program. It also asks the current and incoming students what they expect to achieve in the program. Consequently, it shows whether there is any discrepancy between learners' perceived needs as determined by lecturers and the ones felt themselves, whilst illustrating how the students' needs may evolve from training to practice.

\section{Background of research}

The program focused in the research was established in 1996 within a department of linguistics as a postgraduate program with only two languages, Chinese and Japanese. It later added five other languages including a sign language until 2002. In terms of student numbers, it grew at a remarkable pace from a dozen to over 300 in less than 10 years. The program further improved with the approval a national authority for accreditation of translators and interpreters in 2003 to administer tests for its accreditation.

The national body's approval played an important role not only in increasing student numbers, but also in program reform. As shown below in Figure 1, the program started with a linear type curriculum (Sawyer 2004) leading students from the Postgraduate Diploma to the Master of Arts in Translation and Interpreting in one and a half years. It offers theoretical and practical translation and interpreting subjects in conjunction with related linguistic subjects. With the approval of the national body, the program has added practicum components and standardised its exams to be consistent with the authority's guidelines, which inevitably has resulted in the 
curriculum and syllabus revisions. The program now reviews its performance more rigorously as it is now subject to external audit as well.

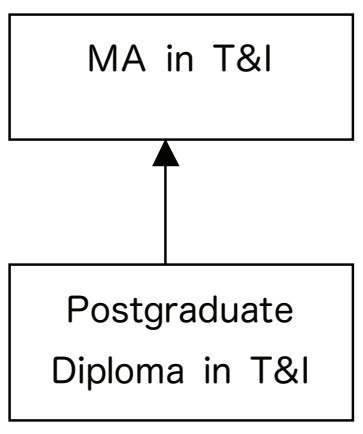

Figure 1. Linear type curriculum

After the program obtained the national organisation's approval in 2003, it continued to evolve further, developing an offshore program abroad, and introducing two new master programs in 2005-Master in Translation and Master in Conference Interpreting. As shown below in the Figure 2, the program now has multiple entry points depending on students' qualifications and personal situations, offering more specialised courses to suit diverse needs. It also means that the program needed to reform its curriculum to reflect all these changes.

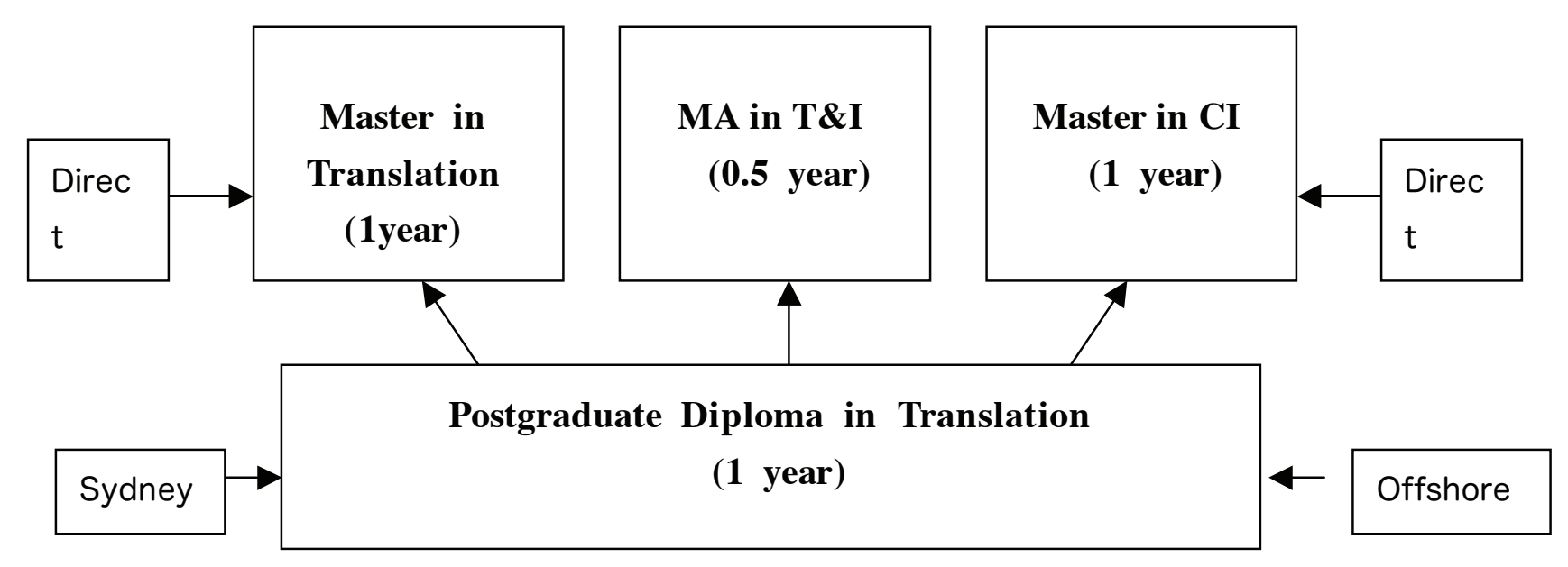

Figure 2. Multi-stream type curriculum 
With the introduction of more specialised courses, there have been discussions within the program regarding the nature of the existing MA program. As it has more than 300 students, it cannot be abolished easily. If it is not carefully managed, it could be treated as a second grade course, giving up good students to specialised courses. If it fails to attract students, then, it could die out naturally. Or it might be revised to meet the needs of a specific group of learners.

Another unique feature of the program is its students' diverse nationality backgrounds. The program receives students almost entirely from overseas-China, France, Japan, Korea, Spanish speaking countries, and Thailand, with the majority of whom goes back to their home countries after their study. For the sign language, we receive local students mainly. This diversity of student backgrounds also plays an important role in the curriculum development, as we have to reflect all different types of market situations in teaching our students.

\section{Needs analysis}

The concept of needs analysis is found in many fields with the best example found in the marketing activities of the business sector. Business people seldom attempt to produce or sell their products to consumers before being convinced they meet their consumers' needs and demands. The same concept has been adopted in the field of education in general, and in language teaching in particular, specifying some aspects of language teaching and learning. It is assumed that when language teaching is focused on what learners are interested in, language learning is most effective. From this principle arises the necessity of needs analysis.

The focus of needs analysis, however, varies depending on what educational philosophy and values it is based. In his state-of-the-art article, West (1994) summarises the development of needs analysis in language teaching. According to West, needs analysis was conducted mainly for English for Specific Purpose (ESP) courses in the 1970s- English for Occupational Purpose (EOP) and English for Academic Purpose (EAP), focusing on the target language analysis. Targetsituation analysis was the most commonly used form of needs analysis for this purpose, establishing the learners' language requirements in the occupational or academic situation they were preparing for (Chambers 1980:29, quoted in West 1994). The curriculum that focuses on the achievement of objectives, rather than the process of how to achieve them, has used the results of this type of needs analysis, that is, product-oriented or perceived needs, for its objective specification. The Munby's model ((1978, as quoted in Nunan 1988) is the most well known approach to target-situation analysis, collecting at a pre-course stage information on the following elements: 1. participant, 2. purpose domain, 3. setting, 4. interaction, 5. instrumentality (medium and mode), 6. dialect, 7. target level, 8. communicative event, 9. communicative key. 
However, as West (ibid.) summarises in four points, it has been criticised by many researchers such as Nunan (1988) and White (1988). First, it is too complex and impractical. As a reaction to it, all subsequent systems of needs analysis have tried to achieve simplicity. Second, the model's communicative needs processor is not learner-centred. It just collects data about the learner rather than from the learner. As a reaction, more recent needs analysis has tried to incorporate the teacher's judgment or involve the learner from the start. Third, Munby did not reflect constraints in the needs analysis procedure. Many (e.g. Frankel 1983: 119; Hawkey 1983:84, as quoted in West 1994) felt that these practical constraints should be considered at the start of the needs analysis process. Fourth, Munby fails to provide a procedure for converting the learner profile into a language syllabus (Richards 1984, as quoted in West 1994).

Entering the 1980s, needs analysis further developed from Munby's model, focusing not only on ESP but also general language teaching with an expanded scope of analysis from target situation analysis to deficiency analysis, strategy analysis, means analysis, and language audits. With the process-oriented curriculum gaining momentum in language teaching, it has become necessary to bridge the gap between product-oriented or perceived needs and learners' wants, subjective or felt needs (Brindley 1989). For this purpose, deficiency analysis is used to take account of learners' present needs/wants as well as the requirements of the target situation (Allwright 1982:24; Robinson 1991:9, as quoted in West 1994). At the same time, with the curriculum's focus on the process of learning, strategy analysis is also needed, while means analysis is required to take into consideration practicalities and constraints in the needs analysis phase. In order to overhaul the overall system, language audits are conducted. These are concerned with the efficiency of the present system, and changes with a view to a future system (Looms 1983:62, quoted in West 1994).

\section{Survey construct}

With the aim of checking whether the learners' needs are met by the program or not and redefining the existing MA course, a questionnaire was constructed to include the features of needs analysis of both curriculum models: from the objectives oriented model investigating the learners' target situations, and from the process oriented model studying strategy, deficiency, and means from the learners' perspective (see Appendix). While the investigation of the target situations will help the program developers specify the objectives and content of teaching and learning, the study of other features, especially the learners' evaluation of teaching objectives set by the teachers, will provide a new insight to teachers in critically assessing their teaching. After all, no matter how well a teacher believes he or she is teaching his/her students, if they do not accept it, it is no use. 
The questionnaire had six sections, 1. Demographic information, 2. Target situations, 3. Skills, 4. Deficiency, 5. Methods of survey, 6. Others. The survey asked the respondents to tick, and to provide both short and as-long-as you like answers to obtain freer expression of their feelings and opinions (Gao 2004; Oppenheim 1992).

The questionnaire was distributed to the past and current Korean students by email in February 2005. They could respond directly revealing their identity to the researcher, or send their response to a representative student who forwarded it to the researcher after removing the identity information.

\section{Survey results}

\section{A. Respondents}

The survey received 44 responses, 22 from the current students and 22 from the past students. As shown in Table 1 below, most of the respondents are scattered over quite recent years, implying that the responses are relevant to the current program.

Table 1. Details of respondents -Study period

\begin{tabular}{|l|l|l|l|l|l|l|l|l|l|l|l|l|}
\hline Year of entry & \multicolumn{2}{l}{$\mathbf{2 0 0 0}$} & \multicolumn{2}{l}{$\mathbf{2 0 0 1}$} & \multicolumn{2}{l|}{$\mathbf{2 0 0 2}$} & \multicolumn{2}{l|}{$\mathbf{2 0 0 3}$} & \multicolumn{2}{l|}{$\mathbf{2 0 0 4}$} & $\mathbf{2 0 0 5}$ \\
\hline Semester & 1 & 2 & 1 & 2 & 1 & 2 & 1 & 2 & 1 & 2 & 1 \\
\hline No of Respondents $\mathbf{( 4 4 )}$ & 1 & 1 & & 1 & 8 & 6 & 4 & 3 & 4 & 6 & 10 \\
\hline
\end{tabular}

\section{B. Target situations}

The markets and the professions that the respondents were/are/will be in were investigated to see if the objectives and content of the program reflect their needs successfully. As some of the respondents answered in more than one answer, the total number of responses in this section does not equal the total number of respondents. 
Table 2. Target situations-Markets

\begin{tabular}{|l|l|l|l|}
\hline Current & 5 & 9 & 9 \\
\hline Past & 7 & 16 & \\
\hline Total & 12 & 27 & 9 \\
\hline
\end{tabular}

As Table 2 shows above, more students have interests in the Korean market, which have been the assumption of the lecturers in the program. Another interesting point, though, was that the Australian market seemed to gain more interest than expected. Moreover, unlike the past students, some of the current students show preference for an overseas market, which might well be the Australian, rather than Korean, market after the study. Then, it means the Australian market could become as important as the Korean market for the Korean students in the near future. The job experience survey summarised below in Table 3 provides more interesting information for the program development purpose.

Table 3. Target situations-professions

\begin{tabular}{|l|l|l|}
\hline Jobs & Current students & Past students \\
\hline Past & & \\
\hline Student & 7 & 4 \\
\hline Company Employee & 5 & 13 \\
\hline Interpreter/Translator & 3 & 0 \\
\hline English teacher & 6 & 5 \\
\hline Current/Future & & \\
\hline Interpreter/Translator & 12 & 9 \\
\hline $\begin{array}{l}\text { Company/government } \\
\text { employee }\end{array}$ & 3 & 8 \\
\hline English teacher & 0 & 4 \\
\hline Other business & 2 & 1 \\
\hline Not specified & 4 & 1 \\
\hline
\end{tabular}


The questionnaire asked the students which professions they were/are/will be in before entering and after finishing the program. While the past students answered the question with their specific jobs, the current students gave their plans or expectations for their future jobs.

As can be seen in Table 3, the current students' past professional backgrounds are more diverse than the past students'. One notable element is that professional interpreters/translators entered the program, probably to enhance their skills. This information could support the program's decision to introduce two specialised courses, attracting more professionals aiming toward their career development.

If we can assume the past students' current jobs could show our graduates' field of work more specifically, the current students' low preference for company/government employee positions and English teaching is contrasted to the past students' involvement in the jobs concerned. In fact, several past students expressed in the last section of the questionnaire their desire to learn about cross-cultural and communication aspects within organisations. It may be helpful to introduce current students to such areas so that they may enhance their awareness about the fields, thereby better preparing them for the future.

C. Translation and interpreting skills

In order to investigate more specifically whether the program meets the students' needs, the questionnaire asked the students which translation and interpreting skills and knowledge taught in class proved helpful for their future/current jobs. The questions in this section were devised in such a way that the students were lead to focus not on the teachers, but on the specifics they learn in class, thereby more freely expressing their opinions about their learning experience without feeling guilty of criticising their teachers. Another point that needs to be noted in this section is that the list of skills was prepared not by the researcher, but by the teachers themselves so that it could be seen more clearly whether the needs perceived by the teachers were in line with the needs felt by the learners.

Table 4. Translation skills-perceived vs. felt needs

Which knowledge and skills class are/will be useful for your job?

\begin{tabular}{|l|l|l|l|}
\hline Skills \& knowledge & $\begin{array}{l}\text { Current } \\
\text { students }\end{array}$ & $\begin{array}{l}\text { Past } \\
\text { students }\end{array}$ & Total \\
\hline Translation theory & 3 & 11 & 14 \\
\hline Ethics & 5 & 11 & 16 \\
\hline $\begin{array}{l}\text { Generic skills including feedback techniques, } \\
\text { email communications, etc }\end{array}$ & 16 & 14 & 30 \\
\hline
\end{tabular}




\begin{tabular}{|l|l|l|l|}
\hline $\begin{array}{l}\text { Research skills obtained in-depth research } \\
\text { projects }\end{array}$ & 8 & 7 & 15 \\
\hline $\begin{array}{l}\text { Presentation skills obtained in translation issue } \\
\text { presentations }\end{array}$ & 9 & 7 & 16 \\
\hline Peer correction and proofreading & 6 & 15 & 21 \\
\hline $\begin{array}{l}\text { Group work skills obtained from translation } \\
\text { group projects }\end{array}$ & 6 & 13 & 19 \\
\hline $\begin{array}{l}\text { Skills obtained from portfolio production } \\
\text { including journal writing }\end{array}$ & 6 & 4 & 10 \\
\hline
\end{tabular}

In case of the translation class, there was some degree of discrepancy between the teacher's perceived needs and the students' felt needs as can be seen in Table 4 above. From the list of skills, it may be said that the some of the products the translation teacher expects her students to obtain from her class are not translation skills themselves. Rather, they are the skills that help them focus on the process of learning (Williams and Burden 1997), and the students do not seem to appreciate their value as much as the teacher does. While the teacher shows a clear preference of research based, learner-centered class, the students do not respond to it with the same level of enthusiasm. Interestingly, however, the past students show more positive response to the teaching than the current students although they specifically express their needs for more detailed feedback on their work from the teachers to improve their interpreting and translation competences and skills.

Table 5. Interpreting skills-perceived vs. felt needs

Which knowledge and skills are/will be useful for your job?

\begin{tabular}{|l|l|l|l|}
\hline Skills and knowledge & $\begin{array}{l}\text { Current } \\
\text { students }\end{array}$ & $\begin{array}{l}\text { Past } \\
\text { students }\end{array}$ & Total \\
\hline Background knowledge & 18 & 20 & 38 \\
\hline Ethics & 5 & 9 & 14 \\
\hline Active listening & 14 & 20 & 34 \\
\hline Paraphrasing & 8 & 17 & 25 \\
\hline Memory extension & 17 & 17 & 34 \\
\hline Note-taking & 15 & 14 & 29 \\
\hline Shadowing (from AtoA) & 7 & 9 & 16 \\
\hline Whispering (from A to B) & 7 & 3 & 10 \\
\hline Sight-translation & 13 & 21 & 34 \\
\hline Dialogue interpreting & 14 & 15 & 29 \\
\hline Consecutive interpreting & 13 & 16 & 29 \\
\hline
\end{tabular}




\begin{tabular}{|l|l|l|l|}
\hline Public speaking skills & 6 & 8 & 14 \\
\hline $\begin{array}{l}\text { Research skills obtained from background } \\
\text { information research }\end{array}$ & 9 & 3 & 12 \\
\hline
\end{tabular}

As for the interpreting class, the teacher's perceived needs are described in terms of specific interpreting skills, and correlate with the students' felt needs (roughly $70 \%$ agreed) except for five skills which obtained below 20responses. Unlike in the translation class, ethics is not valued in the interpreting class, and the students do not favour two interpreting skills, shadowing and whispering. Like in the translation class, the students in the interpreting class do not welcome the research oriented approach.

\section{Deficiency analysis}

When the questionnaire asked the students what they would like to add to the program, the past students were more eager and specific in providing their feedback. The feedback could be grouped largely into three categories, instruction, program content, and facilities. Regarding the instruction, the students would like to have more practice hours with market specific and current materials for both translation and interpreting together with more checking and feedback by the teachers, which is a valid claim for the learners who want to acquire specific skills (Gran 1998). These comments were consistent with their rating of the translation and interpreting skills in the previous section. As for the program content, several past students suggested offering basic psychology and communications units in addition to the practical translation and interpreting units would be helpful for them to work within organizations. This comment is worth considering as quite many of our graduates work in organizational contexts. Some of them also expressed their need for special self and group study space that would not be shared with students from other programs. As our students need to do a lot of group study and practice that involve discussions and speaking-out, they find it hard to use the normal university library. A student would like to have an on-line education facility in the program, and another made an interesting comment on the program review, saying that he would like to have "more honest communications" for it. Together with the students' responses in Section 5 that showed their preference for this type of survey and the interviews with lecturers, this remark indicates that learners do have a keen interest in participating in the program review. 


\section{Conclusion}

The program conducts end-of-semester evaluations regularly for both units and lecturers, asking students in general if the goals and objectives of the units have been clear and achieved, and whether the unit and lecturer have inspired thinking and improved learning, etc. They, however, are not designed to capture the students' specific needs. By devising a survey to investigate them more closely, the program coordinator may obtain valuable information to renew the current program more systematically and rationally.

Based on the analysis of the questionnaire responses discussed above, some specific actions may be taken at the micro and macro level in renewing the program focused in this research. At the micro level, the Korean group lecturers may review the analysis results and consider possible changes to the content and methods of teaching for their Korean students. Although more Australian market oriented materials were incorporated into the practical interpreting and translation units since the program was approved by the national organisation, more weight has been given to the Korean contexts, which may be due to the Korean lecturers' education and work experience backgrounds in South Korea. The survey results indicate that content needs to reflect the contexts of the both markets.

The teaching methods also need to be re-considered for better uptake by the students. While it may be argued that the students sometimes are not aware of what is in the best interests of their future, and therefore, need to be guided by their teachers on what and how to learn, it should also be remembered that the teachers are often solely led by their own beliefs, values, and knowledge that they fail to consider their learners' needs and preferences (Tudor 1996; Woods1996). Then, it needs to be seriously considered by the lecturers whether those skills and knowledge areas marked low by the students still should be taught in class, and if so based on the lecturers' objective evaluation, the methods will have to be changed to deliver them more effectively to the students. With the specific expressions of needs from the students, it is easier for the program coordinator to discuss appropriate changes with the lecturers and learners (Cotterall 2000, Parkinson and O'Sullivan 1990).

At the macro level, it needs to be noticed that the lecturers' pedagogical values are not consistent as illustrated in the lists of target skills and knowledge. Depending on what teachers and learners value most, they focus on different things in classroom activities, thus producing different products (Allwright 2005). Many curriculum experts caution against such inconsistencies in a program (Jeong 2003; Johnson 1989; Stern 1992). Therefore, the survey needs to be expanded to other language groups and check if there exist different sets of learner needs and any inconsistency among lecturers' approaches for the whole program. 
Many stakeholders with different interests, views, and approaches are involved in the development, implementation and evaluation of a program (Johnson 1989). The program that is the focus of this research also has several parties concerned in its operation within and without the program: learners, teachers, department, university, and a national authority. While all the parties' views and interests need to be well coordinated to operate a successful program, the learners' needs should be given the priority as they are the ultimate goal of any education and training program. It does not mean that the program should always succumb to the learners' demands. Rather the program should provide a framework in which the parties involved, especially the learners and the teachers who implement the program in class, negotiating their needs with the sense of ownership towards the program. Learner needs analysis may be considered as a valid starting point in achieving that goal.

\section{REFERENCES}

Allwright, D. (2005): "From Teaching Points to Learning Opportunities and Beyond", TESOL QUARTERLY 39-1. p. 9-31.

BERWICK, R. (1989): “Needs Assessment in Language Programming: From Theory to Practice”, in Johnson, R.K. (ed.), The Second Language Curriculum, Cambridge, Cambridge University Press. p. 49-62.

BRINDlEy, G.. (1989): “The Role of Needs Analysis in Adult ESL Programme Design”, in Johnson, R.K. (ed.) The Second Language Curriculum, Cambridge, Cambridge University Press, pp. 63-78.

CotTerall, S. (2000): "Promoting Learner Autonomy through the Curriculum: Principles for Designing Language Courses", ELT Journal 54-2, p. 109-117.

GAO, X. (2004): “A Critical Review of Questionnaire Use in Learner Strategy Research”, Prospect 19-3, p. 3-14.

GRAN, L. (1998): “In-training Development of Interpreting Strategies and Creativity”, in Translators' Strategies and Creativity (Ann Beylard-Ozeroff, Jana Kralova \& Barbara Moser-Mercer eds), Amsterdam/Philadelphia, John Benjamins, p. 145-162.

JeOng, C. J. (2003): An Evaluation of the First CLT Based English Curriculum for Middle Schools in South Korea: From Theory to Practice, Unpublished doctoral thesis, University of Sydney, Sydney.

Johnson, R.K. (ed.) (1989): The Second Language Curriculum, Cambridge, Cambridge University Press.

MARKeE, N. (1997): Managing Curriculum Innovation, Cambridge, Cambridge University Press.

NunAn, D. (1988): Syllabus Design, Oxford, Oxford University Press.

OPPENHEIM, A.N. (1992): Questionnaire Design, Interviewing and Attitude Measurement,

London, New York NY, Pinter Publishers.

PARKINSON, L. and K. O’Sullivan (1990): “Negotiating the Learner-Centred Curriculum”, in Brindley, G. (ed.) Second Language Curriculum in Action, Sydney, Macquarie University, National Centre for English Language 
Teaching and Research

S AWYER, D. (2004): Fundamental Aspects of Interpreter Education: Curriculum and Assessment, Amsterdam/Philadelphia, John Benjamins.

SeEdhouse, P. (1995): “Needs Analysis and the General English Classroom”, ELT Journal, 49-1, p. 59-65.

STERN, H. H. (1992): Issues and Options in Language Teaching (Allen, P. and Harley, B. eds), Oxford, Oxford University Press.

TUdOR, I. (1996): Learner-centredness as Language Education, Cambridge, Cambridge University Press

WeST, R. (1994): Needs Analysis in Language Teaching, Language Teaching 27-1, p. 1-19.

WHITE, R. (1988): The ELT curriculum, Oxford, Basil Blackwell.

WiLliams, M. and R. Burden (1997): Psychology for Language Teachers: A Social

Constructivist Approach, Cambridge, Cambridge University Press.

Woods, D. (1996): Teacher Cognition in Language Teaching. Beliefs, Decision-making and Classroom Practice, Cambridge, Cambridge University Press.

\section{ANNEX}

Postgraduate Diploma and Master of Arts in Translation and Interpreting

Department of Linguistics

Macquarie University

Sydney, Australia

The purpose of this survey is to investigate the needs of the current and former students of the Macquarie T\&I Programs as part of the program renewal.

Sections

1. Demographic information

2. Target situations

3. Skills

4. Deficiency

5. Methods of survey

6. Others

Section 1. Demographic information

Q1. Study period (m/y): From to 
Q2. Sex: Female/Male

Q3. Age: 23 30/31 35/36 40/41 45/46 50/51

Section 2. Target situations

Q4. What was/is your past/current/future job(s)?

Past:

Current:

Future:

Q5. Where did/do/will you work (South Korea/Australia/Other)?

Past:

Current:

Future:

Q6. In what situations did/do/will you use translation/interpreting skills?

Section 3. Knowledge and Skills

Q7. Which translation knowledge and skills are/will be useful for your job(s)? Please circle the number(s).

1. Translation theory

2. Ethics

3. Generic skills including feedback techniques, email communications, etc.

4. Research skills obtained in in-depth research projects

5. Presentation skills obtained in translation issue presentations

6. Peer correction and proofreading

7. Group work skills obtained from translation group projects

8. Skills obtained from portfolio production including journal writing 
Q8. What other skills would you like to add?

Q9. Which materials were/are/will be useful for your translation practice? Please circle the number(s).

1. Articles from newspapers/magazines

2. Authentic translation texts

Q10. What other materials would you like to use?

Q11. Which interpreting knowledge and skills are/will be useful for your job(s)? Please circle the number(s).

1. Background knowledge

2. Ethics

3. Listening

4. Paraphrasing

5. Memory extension

6. Note-taking

7. Shadowing (from English into English)

8. Whispering (from English into Korean or vise versa)

9. Sight-translation

10. Dialogue interpreting

11. Consecutive interpreting

12. Public speaking skills obtained from speech delivery for interpreting practice

13. Research skills obtained from background research for interpreting assignments

Q12. What other skills would you like to add? 
Q13. Which materials were/are/will be useful for your interpreting practice? Please circle the number(s).

1. Articles from Newspapers/magazines

2. Speeches from websites

3. Dialogue/speeches prepared by students or lecturers

4. Authentic speeches from conferences in which lecturers worked

Q14. What other materials would you like to use?

Section 4. Deficiency

Q15. How much helpful was/is/will the unit (be) helpful for you? Please evaluate it from 0 (not at all) to 5 (very much).

TRAN812

$\begin{array}{llllll}0 & 1 & 2 & 3 & 4 & 5\end{array}$

Computing in Translation

TRAN816

0

2

3

4

5

Theory and Practice of Translation and Interpreting

TRAN819

0

Introduction to Text Analysis

TRAN820

0

\begin{abstract}
1
\end{abstract}
2

3

4

5

Translation Practice

TRAN821

0

1

2

3

4

Interpreting Techniques

TRAN822

0

1

2

3

4

Interpreting Practice

TRAN823

0

2

3

4

5

Language Transfer in the Media

TRAN825

0

Lexicography

TRAN826

0

Community Translation and Interpreting

TRAN827

0

Research Methods in Translation and Interpreting

TRAN830

Dissertation

TRAN832

1

2

34


Public Speaking

TRAN833

Writing Skills for Translators

TRAN834

Advanced translation

TRAN900

Grammar, Meaning and Discourse

TRAN903

Languages and Cultures in Contact

TRAN904

Pragmatics

TRAN907

Stylistics and Translation of Literature

International Relations units

Business units

0

$$
1
$$

2

3

4

5

0

1

2

3

4

5

0

1

2

3

4

5

0

1

2

3

4

5

0

1

2

3

4

5

$\begin{array}{llllll}0 & 1 & 2 & 3 & 4 & 5\end{array}$

\section{re}

